\title{
The oldest art in the world
}

\author{
RoBert G. BEDNARIK *
}

\section{ABOUT THE OLDEST ROCK ART}

Despite the fact that nearly all the rock art of the world remains undated, and that not even an approximate estimation of antiquity has been established for many major corpora of rock art, claims to have located or dated the oldest rock art in the world have been made in respect of every continent except North America and Antarctica. Admittedly, the notion that northeast Brazilian paintings may date from before 32,000 years BP (GUIDON and DELIBRIAS 1986) has never been promoted with much vigour, and I have even viewed the lesser minimum dating claim of 17,000 BP for Pedra Furada's rock paintings with some scepticism (BEDNARIK 1989a). Laminar exfoliation processes in that sandstone shelter, disturbed sediments and the preservation conditions in the site's water-logged strata render the postulated early art unproven. At Toca do Baixão do Perna I, another site en the same region, paintings are clearly about 10,000 years old (BEDNARIK 1989a; BAHN 1991A). Older rock art may well exist in South America, but it has not been convincingly dated.

The "earliest artistic productions in the world dated via the $\mathrm{C} 14$ method" have been attributed to southern Africa (ANATI 1986), citing Wendt's (1974) finds of portable paintings in Apollo 11 Cave, Namibia, which are about 26,000 to 28,000 years old. However, Anati's suggestion that Tanzanian rock art is more than 40,000 years old, and sis likely to have begun earlier than any other rock art... the world over" seems to be without support. The occurrence of ochre at levels up to 29,000 years old (at Kisese) si not sufficient: firstly, ochre has been used by hominidis of the very much earlier Acheulian of Europe and Asia, and secondly, ochre use does not necesarily prove that art was produced. Even in Africa, mucho earlier evidence of ochre use than that of Tanzania exists, for instance from the Charama levels of Bambata and Pomongwe Caves in Zimbabwe (KLEIN 1978), which are probably older than 125,000 years. Two

* International Federation of Rock Art Organizations (IFRAO), Melbourne, Australia. 
lumps of "ochre" (more correctly, red volcanic tuff; OAKLEY 1981; 207) were also found in the Developed Oldowan levels at Olduvai BK II, Tanzania (LEAKEY 1958), although they lack utilization traces, and ochre occurs in large quantities in the Acheulian of Wonderwork Cave, South Africa, where it appears to be up to 800,000 or so years old (BEDNARIK 1993a). Ochre mining has a long history in Africa, for example a radiocarbon date of $43,200 \mathrm{BP}$ was obtained from the large ochre mine of Lion Cavern in South Africa (BEAUMONT and Boshier 1972).

A similar lack of substantiating evidence applies to the claim that Indian rock painting may be up to 40,000 years old (WAKANKAR 1983). Tyagi (1992) and others have shown that the supposedly Upper Palaeolithic painting in central India of often green, dynamic figures are preceded by non-iconic arragements, the «intricate patterns". The anthropic origins of nearly all of the markings on Indian ostrich eggshell fragments of the Pleistocene (KUMAR et al. 1988) have been refuted (BEDNARIK 1992a, 1993b). Nevertheless, Pleistocene rock art probably does exist but in the form of petroglyphs rather than paintings (BEDNARIK et al. 1991), and among them may well be the oldest known rock art in the world (BEDNARIK 1992A, 1993C). The notion that Siberian rock art at the sites Shishkino and Tal'ma has been shown to be of the Pleistocene has been refuted on the basis that the supposed picture of a rhinoceros at Tal'ma does not exist, and that there is no objective evidence favouring these claims (BEDNARIK and DeVLet 1992). Likewise, claims for the depiction of extinct giraffes, ostriches and large-antlered deer in Inner Mongolia, China, have been similarly discounted (BEDNARIK and LI 1991).

The most widespread belief concerning the question of the oldest art in the world is that the Upper Palaeolithic art of western Europe represents the oldest artistic tradition. It is also in Europe that the first claims of a rock art tradition of up to forty millennia appeared, again without substantiation. Older traditions than those of Franco-Cantabria may exist in central Europe, Africa and Asia, and they certainly do exist in Australia. Most of the Upper Palaeolithic rock art and portable art actually belongs to the Magdalenian, the most recent tradition of this period, and is less than 18,000 years old. Only a small proportion may be of the Solutrean, Gravettian or Aurignacian. Nearly all of the western European Pleistocene rock art remains undated, and most of the recently derived direct dates of cave paintings disagree with the previous archaeological or stylistic dating of the motifs in question. The oldest direct dates from European rock art are two radiocarbon ages from one black hand stencil in Cosquer Cave, of 27,111 $\pm 390 \mathrm{BP}$ and $27,110 \pm 350 \mathrm{BP}$ (CLOTTES et al. 1992) which provide only maximum ages for the art in question (BEDNARIK 1993d). Aurignacian rock art can be expected to be somewhat older, but could 
certainly not match the already available Australian minimum ages of around 45,000 years.

There has long been an expectation that Australian rock art would be shown to be among the oldest in the world, but proof had been lacking. Recent direct dating has changed this, but the art concerned is not the painted art of Arnhem Land or Cape York, as had been proposed, it consists of deeply patinated petroglyphs in South Australia and possibly elsewhere in Australia. Three sites have now produced direct dates well in excess of 30,000 BP, and they are located within a few kilometres of each other. Some of these dates were obtained with the controversial cation-ratio method (NOBBS and DORN 1988), but these correspond reasonably well with AMS radiocarbon dates from the same sites. Three of the four oldest dates currently available, which range from 36,400 (DORN et al. 1992 ) to 45,100 years BP (BEDNARIK 1992b), are in fact radiocarbon dates, and they are conservative minimum dates: the underlying petroglyphs are expected to be older still. These dates come from the sites Wharton Hill and Panaramitee North. They were obtained from organic matter concealed under the rock varnish covering the motifs, so they are considered to be minimum ages for the rock art. The oldest directly dated rock painting in Australia is about 24,600 years old (WATCHMAN 1992). It must be emphasized here that, whilst the oldest currently dated rock art is in Australia, probably older rock art is likely to exist elsewhere. The Mousterian cupules from La Ferrassie could be considered here, as well as those from Bhimbetka (BEDNARIK 1992a, 1993c, 1993e).

\section{ABOUT THE OLDEST PORTABLE ART}

The record of portable art in Europe is again said to begin with the Aurignacian, or with Aurignacoid traditions. However, the oldest known evidence of iconic art is not from western Europe, but from central Europe and Siberia. Highly expressive and sophisticated ivory and stone sculptures have been found in southern Germany and Austria (Figure 2): at Galgenberg (BEDNARIK 1989b), Hohlenstein-Stadel (HAHN 1971), Vogelherd (RIEK 1934) and Geissenklösterle. The are around 32,000 years old. No comparable, well dated portable art has been reported from the FrancoCantabrian region, but a similarly naturalistic sculpture has been found on a woolly rhinoceros vertebra found at Tolbaga, south-central Siberia (Figure 3) which seems to be about 35,000 years old (ABramova 1990).

However, older evidence of artistic or non-utilitarian activities does exist in various parts of Europe. Engravings and apparently artificial notches have been reported on bone remains from the Mousterian from La 
Quina (MARTIn 1907-10), Petit-Puymoyen, abri Lartet, abri Suard (DebenATH and DUPORT 1971) and La Ferrassie in France (CAPITAN and PEYRONY 1921); Cueva Morín, Spain (Freeman and Gonzalez Echegaray 1983); Bacho Kiro, Bulgaria (MARSHACK 1976); Tagliente rockshelter, Italy (LEONARDI 1988); as well as from French Charentian sites (BouvieR 1987). A serrated bone fragment has been reported from the Mousterian of Schulen, Belgium (HuYGE 1990). Non-figurative Mousterian engravings have also been found on stone, at several sites in Italy (LEONARDI 1988) and Hungary (VÉRTES 1964, 1965) (Figure 4).

From the Africam Pleistocene, figurative portable art has been reported only from Apollo 11 Cave, Namibia, as mentioned above. Older bone objects with serrations are also known, from the Middle Sotne Age of several sites: Klasies River Mouth, South Africa (SINGER and WYMER 1982), Border Cave, Swaziland (BEAUMONT et al. 1978) and Apollo 11 Cave (WENDT 1974). A wooden fragment with engraved lines comes from the Middle Stone Age of Florisbad, Orange Free State (VOLMAN 1984), and engraved ostrich eggshell fragments from that of the Howieson's Poort phase of Apollo 11 Cave and Diepkloof Cave in the southwestern Cape (BEAUMONT 1992).

The oldest portable art of Asia presents an even more fragmentary record. While Upper Palaeolithic art objects have been found at about twenty Siberian sites (ABRAmova 1990; BedNARIK 1994a), only a single Palaeolithic art find has been made in China, and only very recently (BEDNARIK 1992c). Similarly, only few sites of Pleistocene art are known in Japan (AIKENS and HIGUCHI 1992; BENARIK 1994a). In India, too, only one portable art object can be attributed to the Palaeolithic period (BEDNARIK 1992a, 1993b, 1993c) (Figure 5). In Israel, the scoria pebble from Berekhat Ram, which has a natural form of a female torso and head, is claimed to bear engraved grooves emphasizing its form. It comes from a sealed deposit that is more than 233,000 years old, and is associated with an Acheulian tool industry (GOREN-INBAR 1986). The incised bones from Kebara Cave, Israel, are of the Mousterian (DAvIs 1974). Thus it appears that the information available about Asian Pleistocene art is far too fragmentary to form any conclusions. No Pleistocene portable art has been reported so far from both Australia and South America, and in North America it is restricted to a single possible specimen, the animal head from Tequixquiac, Mexico (BAHN 1991b), which may be of the final Pleistocene. However, Chaffee et al. (1993: 71) have dated a fragment of a pigment ball that seems to have been worn as an ornament to over 15,000 years BP, at the Brazilian site Perna I.

A common argument that perforation of small objects such as animal teeth begins with the Upper Palaeolithic is as much a myth as the same 


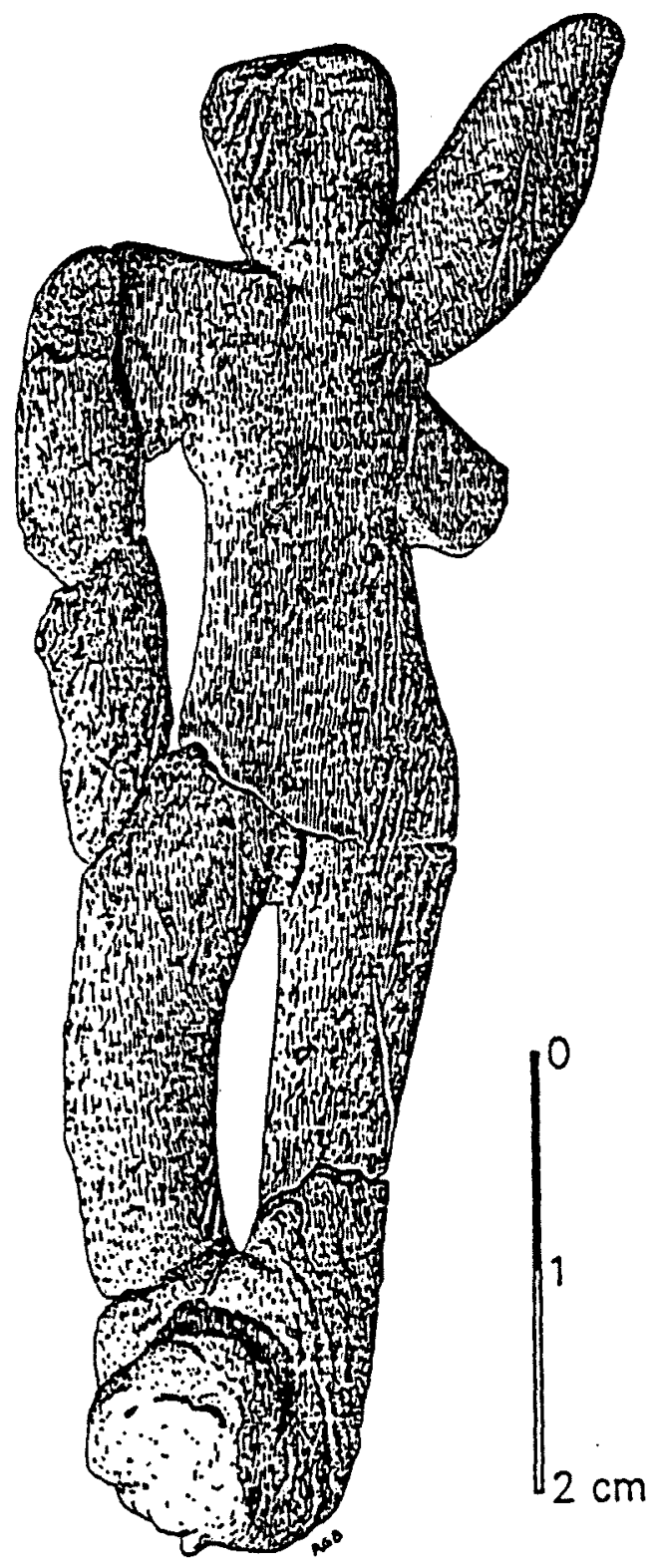

Fig. 2. Small sculpture of serpentine, Galgenberg near Krems, Lower Austria. The Aurignacoid occupation layer it comes from yielded six radiocarbon dates, the one nearest to the figurine is $31,790 \pm 280 \mathrm{BP}$ (Bednarik 1989). This is the oldest known stone sculpture. 


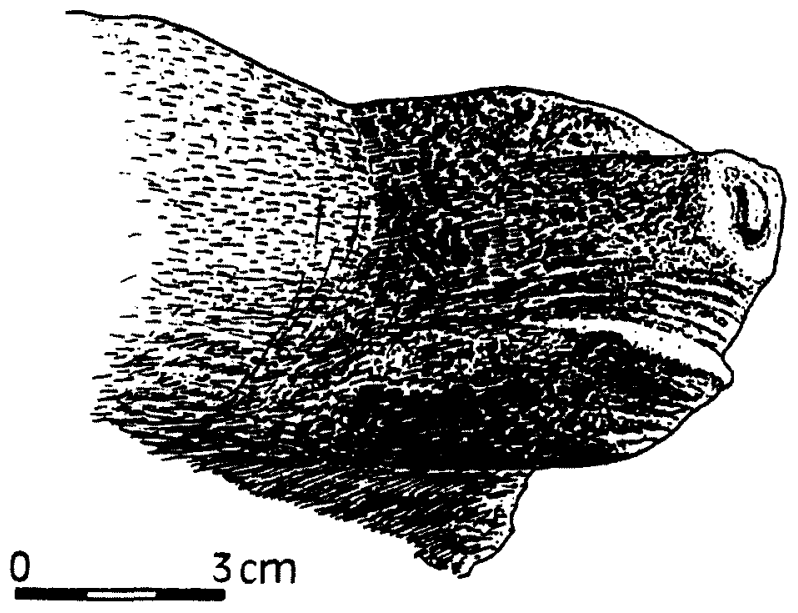

Fig. 3. Sculpture of an animal head (perhaps of a bear) on a vertebra of the woolly rhinoceros from Tolbaga, Siberia. Probably about 35,000 years old.

claims for art. It is probably true that most such objects are non-utilitarian (decorative), the alternative possibilities mentioned by Chase and Dibble (1992) notwithstanding, but they were certainly first produced well

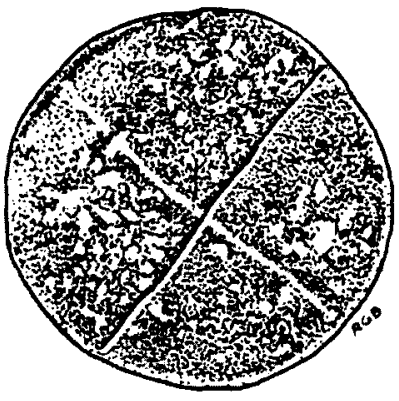

Fig. 4. Fossil, silicified nummulite, from the Mousterian of Tata, Hungary. The partially translucent disc is dissected by a natural fracture, the second line was engraved on both sides at right angles to the fracture.

before to the Upper Palaeolithic. The oldest known perforated stone objects come from Shiyu, China (BEDNARIK and You 1991) and Kostenki 17, Russia (BEDNARIK 1992d). There are numerous perforated bones and teeth from Micoquian, Mousterian and Proto-Aurignacian contexts (see 


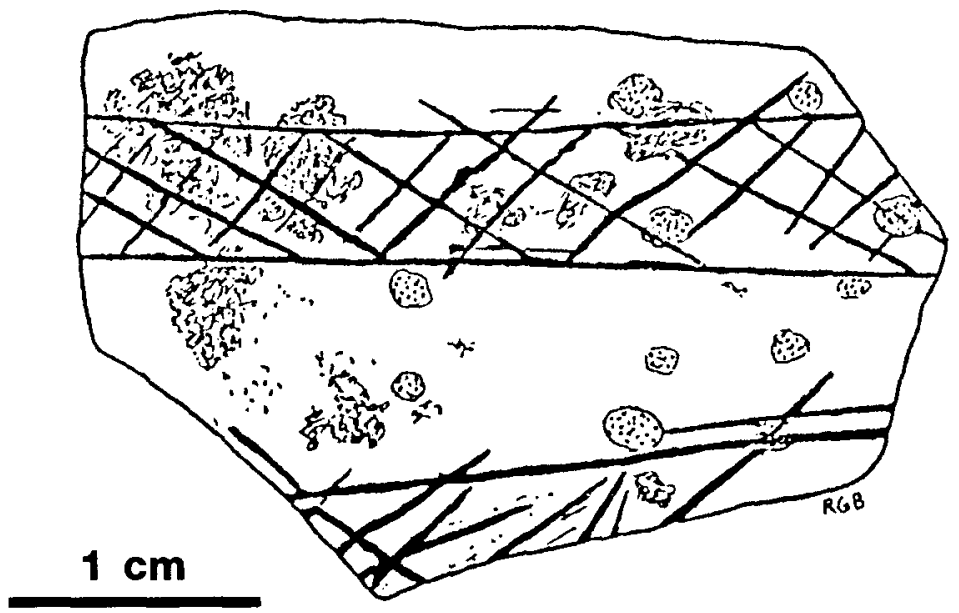

Fig. 5. Engraved ostric eggshell fragment, early Upper Palaeolithic, Patne, India. Approximately 25,000 years old, this is the oldest portable art object currently known in Asia (Bednarik 1992a). Much older engraved ostrich eggshell occurs in southern Africa.

BEDNARIK 1992d), and two specimens from one site have been claimed to date from the Lower Palaeolithic. They are from the Repolust Cave, Austria (BEDnARIK 1992d, Fig. 3). Although the age of this last claim requires verification, it is relevant to note that microwear traces on Acheulian stone tools have indicated that perforation was practised in some Lower Palaeolithic cultures (KEELEY 1977).

\section{LOWER PALAEOLITHIC EVIDENCE}

This raises the question of non-utilitarian behaviour traces from the Lower Palaeolithic. The Berekhat Ram "proto-sculpure" has been mentioned already, but there are several other finds that have been suggested to indicate very early "artistic" practices. The site of Bilzingsleben, Germany, has produced not only a handaxe-free Lower Palaeolithic stone tool industry and several skeletal fragments of late Homo erectus, it yielded also more than four bone artefacts with intentional engravings (Figure 6) (MANIA and MANIA 1988), as well as one engraving on a small quartzite slab (BEDNARIK 1992d). These finds are from the Holstein interglacial and are thought to be between 250,000 and 350,000 years old. A set of 
engraved lines has also been found on a bone fragment from Stránská skála, Czech Republic (VALOCH 1987), again at a site that produced remains of Homo erectus. Earlier, Bordes (1969) had reported an engraved bone from the Acheulian of Pech de l'Azé, of a roughly similar age.

The use of ochre or haematite is well attested for the Acheulian of several sites, in Europe, Africa and Asia. While it does not necessarily prove that such pigments were used for «artistic" purposes, there is a good probablility that they were. If the pebbles were ground to powder, the ochre probably served as paint, which could have been body paint, for instance. However, pebbles with striated wear facets were probably hand-held and rubbed against a rock surface, i.e. they were used as crayons. Thus they do indicate some form of artistic activity. Such striated haematite pebbles were found at two Acheulian sites: Beçov, Czech Republic (MARSHACK 1981) and Hunsgi, India (BEDNARIK 19900. There are several facetted pieces of limonite among the seventy-five found at Terra Amata, France (DE LUMLEY 1966), and an apparently shaped slab of ochre was reported from Ambrona, Spain (HowELL 1966). In both cases, the pigment is again from Acheulian strata. In Africa, ochre use can be demonstrated at Wonderwork Cave to about $800,000 \mathrm{BP}$, as mentioned above. Middle Palaeolithic evidence of ochre use is quite common in the Old World. In Australia, very hard, striated haematite is found from the earliest known occupation levels onwards (JONES 1985; ROBERTS et al. 1990).

Incised markings, rare petroglyphs and the use of colouring agents are not the only evidence suggesting that the hominids of the Lower Palaeolithic had non-utilitarian practices. Much relevant evidence is less direct, but it can help us nevertheless in considering the cognitive abilities of these hominids. For instance, colour use and colour discrimination can be assumed to involve colour preference. The evidence from Europe, southern Africa, India and China (possibly also Israel) that Lower Palaeolithic people collected small crystals, fossil casts and oddly shaped pebbles seems to provide adequate proof that they were capable of discriminating between unusual and common objects, finding the former sufficiently interesting to collect them and carry them to their home-bases BEDNARIK 1992e). This does not provide evidence of symbolism, but it does suggest a mind that had begun creating taxonomies in the object world. Differentiation between rare and common objects is a non-utilitarian capacity, and together with the few specimens of engraved portable objects, the numerous spherical or discoid stones from China, India, Africa and Europe (BEDNARIK 1992d) and te well-attested use of colouring agents, there seems to be sufficient evidence to look for the origins of art in the Lower Palaeolithic. 

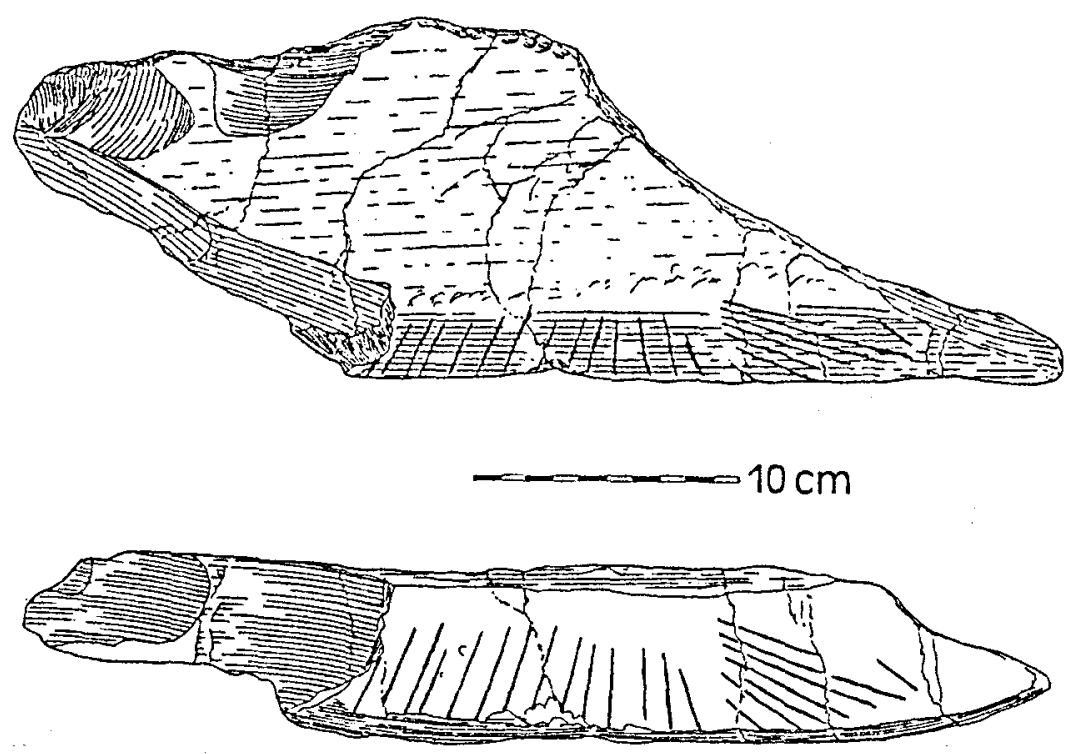

Fig. 6. One of the engraved bone artefacts from the Lower Palaeolithic of Bilzingsleben, Bermany. Fragment of elephant tibia, Holstein complex, Mindel/Riss interglacial.

\section{DISCUSSION OF THE EVIDENCE}

The above summary of early art finds excludes many others that have been mentioned in the literature and which I am either aware of or have examined myself, but which I do not regard as authentic evidence of artistic production (for instance, over 600 specimens in China alone). This outline shows, firstly, that any hypothesis based on the frequent claims that the Upper Palaeolithic art of Franco-Cantabria marks the beginning of art is fundamentally flawed, unless it were predicated on a Eurocentric concept of what art is. Secondly, the record suggests that there is no simple answer to the question of art origins. Art was neither "invented" in one part of the world, nor at any particular point of time. Its slow development is as complex as human evolution itself, it probably occurred in many parts of the world and in the form of complex, intertwined processes that began in the Lower Palaeolithic.

But this record tells us mucho more. Its most obious characteristic, and the one that we should heed most to curb our desire to interpret the 
evidence, is its profound incompleteness. If one examines the evidence most closely it becomes quite obvious that all regional corpora of early art are poorly connected, geographically as well as chronologically, in fact in many cases they consist of no more than a single specimen. What is so often considered to constitute a representative record of early art development provides in fact no more than a few random peep holes to view "some" of these developments. In all examples of extant Pleistocene art, almost miraculous combinations of circumstances are responsible for their survival (BEDNARIK 1992f: 263). To understand the full scale of misinterpretation of Pleistocene art one needs first to considerer that the surviving record is totally anomalous, having been distorted by countless taphonomic processes. The statistical probablity of the extant record of palaeoart being a representative sample is practically nil. Because the effects of taphonomy have generally not been considered in interpretational hypotheses about palaeoart (BEDNARIK 1994b), all such hypotheses are scientifically invalid. It is obvious that the distributional, statistical and compositional characteristics of such extremely fragmentary evidence must be almost entirely the result of taphonomy, and the part of them that is attributable to the processes of art production itself is not only minute, it cannot be readily identified. Thus the precondition of a "scientific study of the art is the identification of that part of the extant characteristics of the evidence that is not a result of taphonomy".

As if this encumbrance were not enough to place in doubt all interpretations of early art, the discipline has in effect superimposed on it another impediment to its own credibility, which is just as fatal. Its insistence on concentrating, in questions of art origins, almost entirely on the art of the Upper Palaeolithic of Europe constitutes an arbitrarily selective agent which is attributable to a complex set of subjetctive preoccupations of individual scholars or scholarly traditions. As a result, a small geographical spectrum has been selected from an already heavily distorted record, and presented (and promoted) as representatively reflecting the early artistic developments of humans. Effectively, this limits the sample being admitted in a quantitative sense, after it has already undergone the severe qualitative screening process of taphonomy (see BEDNARIK 1994b).

The results of selecting the rather exceptional art corpus of the western European Upper Palaeolithic (BEDNARIK 1993f) were predictable. Scholars ignored the world-wide evidence that non-figurative arts precede figurative graphic arts (BEDNARIK 1984a, 1986, 1987, 1988). They also ignored that there are several possible alternative explanations to their models of the role of Franco-Cantabrian cave art and European mobiliary art traditions - alternatives which are more realistic, more plausible, 
and in all probability more correct. For instance, the sudden appearance of sophisticated sculpture in central Europe probably does not reflect real developments in art production, it is far more convincingly explained as the extant record of a shift in the preferred materials, from perishable to non-perishable materials (BEDNARIK 1989b). The marked increase in the utilization of bone, antler and ivory is a hallmark in the tool production of the Göttweig interstadial, and it is likely that this shift is also reflected in the art production of the period. Moreover, it would be quite illogical to interpret the apparent paucity of pre-Upper Palaeolithic art as confirming that art production began with the Aurignacian, because it ignores the principle of cumulative taphonomic sample reduction effects on early evidence of symbolic behaviour. That principle simply demands that there must be a period of art production from which almost no evidence can have survived (BEDNARIK 1992f: Fig. 1).

Another erroneous claim by those promoting the significance of European Upper Palaeolithic art concerns the often postulated symbolism of much of this art. The most outstanding feature of this art is its high content of iconic (figurative) motifs, which is absent in all other Pleistocene arts, especially in graphic arts (BEDNARIK 1991, 1993f). Yet there is no reason why figurative art needs to be symbolic to have a function. It is not associated with its referent through symbolism, but through iconicity. Thus it is actually the non-west European Pleistocene arts (e.g. those of Siberia, Russia, Australia) that provide the most extensive evidence of Pleistocene symbolism.

The Australian corpus of probable Pleistocene rock art is many times as great as that of Europe, consisting as it does of hundreds of thousands of motifs (BEDNARIK 1986: 164). Part of it is also significantly older than the Upper Palaeolithic art of Europe. A comparison of the claims made regarding these two respective art traditions is most illuminating. Those concerning the significance and meaning of western European "cave art" are largely unscientific, most having been made without due regard for evidence from other world regions. For almost a century, there have been almost innumerable claims of the chronological precedence of this art, which have given rise to the myth that art, language and human self-consciousness first emerged in the Upper Palaeolithic of western Europe. The unquestioning acceptance of this myth is so entrenched in the literature that it will take decades to eradicate it effectively.

By comparison, hardly any such frivolous claims have been advanced for Australian rock art. Indeed, its great antiquity was postulated only "after» credible direct dating evidence had become available, even though it had been suggested since early this century (e.g. BASEDOw 1914). 
Despite the now obvious fact that the oldest currently dated art is in Australia, not a single writer has even as much as suggested that art first appeared in Australia. On the contrary, Australian commentators have emphasized their views that art was first produced outside of Australia. Irrespective of whether they prefer scientific (BEDNARIK 1992f) or humanistic approaches (DAVIDSON 1992) to palaeoart studies, Australian commentators do agree that art was probably introduced by the first settlers of Australia (BeDnARIK and You 1991). Assuming that the first Australians came from Asia, this demands that a tradition of art production must have existed there prior to the initial settlement of Australia, which is now believed to have taken place at some point between 50,000 and 140,000 years ago. This commendable restraint by the Antipodean researchers provides a stark contrast to the colourful, fascinating but ultimately worhless folklore that has been built around the Pleistocene rock art of Europe.

It is also instructive to compare the imaginative claims of European researchers concerning the perceived aesthetic sophistication of the animal figures often found in Franco-Cantabrian rock art, with the reaction to the much older Australian petroglyphs. By emphasizing the part of Upper Palaeolithic art which subjetive researchers were able to relate to most easily, i.e. the figurative component, they trivialized the art with their ethnocentric and fanciful preoccupation with aesthetics. Figurative motifs need not have symbolic functions, and such pictures are cognitively unsophisticated. By comparison, the currently oldest dated rock art motif in the world, one of the mazes at Panaramitee North (Figure 1) which is at least three times as old as the simple animal images of Lascaux or Altamira, is of greater cognitive complexity. The painstakingly executed remnant of a once much larger maze comprises the spiral, a motif appearing in Palaeolithic art only much later, at Mezin and Isturitz. The maze is of a conceptual complexity that suggests to me that the Middle Palaeolithic settlers of Australia were cognitively more evolved than the Upper Palaeolithic artists of Europe, but that they perceived a reality that differed significantly from ours, or from that of Upper Palaeolithic Europeans. In their conceptual system of the world, meaning was perhaps derived from properties or taxonomies quite different from those we tend to emphasize. Since our own way of experiencing reality lacks substantial scientific verification (in fact it is not in tune with advanced concepts of theoretical physics), we should not assume that the perhaps significantly different reality (or realities) of Middle Palaeolithic people was any less valid. A level of material success provides no reliable measure of the validity of concepts of reality, and the pernicious tendency of contemporary Westerners to arrogantly assume that their own experien- 
ce of reality is the only valid one continues to be the greatest single menace to the objectivity of scientific enquiry. Seen in this context, the question of the oldest art takes on a whole new meaning. It becomes a search for the cognitive processes that conceivably led to human constructs of reality (BEDNARIK 1984b, 1985, 1986, 1992e, 1994c).

\section{THE OLDEST ART}

It has become evident in this paper that our record of Pleistocene art is far too fragmentary to expect being able to identify the oldest art tradition, or even just the oldest surviving art tradition. In fact it appears likely that the oldest art will never be found. Not only is it most unlikely to have survived, even if we saw it we would probably not be able to recognize it, beçause it may relate to cognitive parameters to which we have no access. The developments that led to art remain shrouded in mystery, we do not know what these processes were or how their products could be detected in the archaeological record. Indeed, we cannot even expect a clear-cut differentiation between activity traces that may have led to art, and artistic productions themselves. For instance, such activity traces might include marks resulting from rhythmic manipulation of objects (e.g. tapping on a piece of wood or bone with a stone tool), which could have left marks on them, permanent marks that externalized sound, meaning and rhythm. Not only would this lead to an increasing consciousness of the physical reality and to a cognitive feedback on the visual impact of mark production, it would inevitably result in a visually more complex environment, and in the emergence of mental processes facilitating a taxonomization of physical reality. Initial marking activities of various types would be adopted by stimulus-seeking hominids. Optimal level of arousal is of survival value to any species (BERLYNE 1960), and exploratory or ludic behaviour almost certainly precipitated cognitive evolution and the introduction of art-producing behaviour.

This is where the origins of art are to be found, and the evidence may be reflected in such practices as collecting crystals and other exotic objects in the early Lower Palaeolithic (D'ERRICo et al. 1989; BEDNARIK $1992 d, 1993 a)$. By 300,000 to 200,000 years ago, incised marks on portable objects and coloured marks on rock surfaces suggest that marking traditions had become established in which hominids re-shaped salient aspects of their physical environment, and were engaged in formulating taxonomic frameworks facilitating conscious perception.

Middle Palaeolithic people produced conceptually complex markings which were capable of communicating meaning, and were susceptible to 
conscious mutation and cultural utilization. The use of phosphene motifs proliferated from that time onwards (BEDNARIK 1984b, 1986, 1987). It is likely that figurative sculptured art was also produced then, but there are no finds of it until the beninning of the Upper Palaeolithic of central Europe. Graphic figurative art, indicative of a conscious perception similar to that of extant humans, appears soon after 30,000 BP, essentially taking the development of art to what we understand by it today. Thus there have been no significant cognitive innovations in graphic art since the time of the Franco-Cantabrian artists, only improvements in technique. The same may well apply to cognitive perception generally, and our own perceived rality is basically a product of the Palaeolithic. Indeed, the intellectual innovations of Homo sapiens sapiens seem rather less impressive than those of his predecessors.

\section{BIBLIOGRAPHY}

ABRamova, Z.A. (1990): “L'art mobilier paléolithique en Siberie", Bollettino del Centro Camuno di Studi Preistorici 25/26, 80-98.

AIkENS, C.M., and HıguCHI, T. (1982): Prehistory of Japan. Academic Press, London/New York.

ANATI, E. (1986): "The rock art of Tanzania and the east African sequence", Bollettino del Centro Camuno di Studi Preistorici 23, 15-68.

BAHN, P.G. (1991a): "Dating the first American", New Scientist 20 July, 18-20.

- 1991b: "Pleistocene images outside Europe", proceedings of the Prehistoric Society 57 (1), 91-102.

BASEDOW, H. (1914): "Aboriginal rock carving of great antiquity in South Australia", Journal of the Royal Anthropological Institute 44, 195-211.

BEAUMONT, P. (1992): The time depth of aesthetic and symbolic behaviour in southern Africa. Paper presented to the Biennial Conference of the Southern African Association of Archaeologists, Johannesburg.

BEAUMONT, P., and BOSHIER, A. (1972): "Mining in southern Africa and the emergence of modern man», Optima, March 1972 issue.

Beaumont, P.; De Villiers, H., and Vogel, J. (1978): "Modern man in sub-Saharan Africa prior to 49,000 BP: a review and evaluation with particular reference to Border Cave», South African Journal of Science 74, 409-19.

BEDNARIK, R.G. (1984a): "Die Bedeutung der paläolithischen Fingerlinientradition", Anthropologie 23, 73-79.

- (1948b): "The nature of psychograms", The Artefact 8, 27-32.

- (1986): "Paietal finger markings in Europe and Australia", Rock Art Research 3, 30$61,159-70$.

- (1987): “Engramme und Phosphene", Zeitschrift für Ethnologie 112 (2), 223-35.

- (1988): "Comment on F.D. Mc Carhy, "Rock art sequences: a matter of clarification", Rock Art Research 5, 35-38.

- (1989a): "On the Pleistocene settlement of South America", Antiquity 63, 101-11.

- (1989b): "The Galgenberg figurine from Krems, Austria", Rock Art Research 6, 11825.

- (1990): “An Acheulian haematite pebble with striations", Rock Art Research 7 (1), 75.

- (1991): "Asian palaeoart and Eurocentric science", Purakala 2, 71-76.

- (1992a): "The Paleoloithic art of Asia". In S. Goldsmith, S. Garvie, D. Selin and J. Smith (eds.), Ancient images, ancient thought: the archaeology of ideology, 383-90. Proceedings of the 23rd Annual Chacmool Conference, University of Calgary. 
- (1992b): "Oldest dated rock art - a revision", The Artefact 15, 39.

- (1992c): "Palaeolithic art found in China", Nature 356, 116.

- (1992d): “Palaeoart and archaeological myths», Cambridge Archaeological Journal 2 (1), 27-43.

- (1992e): "On Lower Paleolithic cognitive development". In S. Goldsmith, S. Garvie, D. Selin and J. Smith (eds.), Ancient images, ancient thought: the archaeology of ideology, 427-35. Proceedings of the 23rd Annual Chacmool Conference, University of Calgary.

- (1992f): "The stuff legends in archaeology are made of: a reply to critics", Cambridge Archaeological Journal 2 (2), 262-265.

- (1993a): "Wonders of Wonderwork Cave", The Artefact 16: 61.

- (1993b): "About Palaeolithic ostrich eggshell in India", Indo-Pacific Prehistory Association Bulletin 13: 34-43.

- (1993c): "Palaeolithic art in India", Man and Environment 18.

- (1993d): "Cosquer Cave dating", The Artefact 16: 58.

- (1993e): "About cupules», Rock Art Research 10: 138-9.

- (1993f): "European Palaeolithic art - typical or exceptional?", Oxford Journal of Archaeology 12 (1): 1-8.

- (1994a): "The Pleistocene art of Asia", Arts Asiatiques (in press).

- (1994b): “A taphonomy of Pleistocene art», Antiquity (march issue).

- (1994c): “Rock art, taphonomy and epistemology", Australian Archaeology (in press).

BednARIK, R.G., and DeVLET, K. (1992): "Rock art conservation in Siberia", Purakala $3(1+2)$ : 3-11.

BEDNARIK, R.G.; KUMAR, G., and TYAGI, G.S. (1991): "Petroglyphs from central India", Rock Art Research 8, 33-35.

BEDNARIK, R.G., and LI FusHUN (1991): "Rock art dating in China: past and future", The Artefact 14, 25-33.

BednARIK, R.G., and You Yuzhu (1991): “Palaeolthic art from China”, Rock Art Research 8, 119-23.

BERLYNE, D.E. (1960_: Conflict, arousal and curiosity. McGraw Hill, New York.

Bordes, F. (1969): "Os percé mousterién et os gravé acheuléen du Pech de l'Azé Il", Quaternaria 11, 1-5.

BOUvier, J.-M. (1987): "Bases objectives de la chronologie de l'art mobilier en Périgord, Charente et Poitou', in Pré-actes, Colloque International d'Art Mobilier Paléolithique, 13-20, Foix.

CAPITAN, L., and Peyrony, D. (1912): "Station préhistorique de la Ferrassie, commune de Savignac-du-Bugue (Dordogne)", Revue Anthropologique 22, 76-99.

- (1921): "Les origines de l'art à l'Aurignacien moyen: La Ferrassie", Revue Archéologique 31, 92-112.

ChafFeE, S.D.; Human, M., and Rowe, M. (1993): "AMS ${ }^{14} \mathrm{C}$ dating of rock paintings", in J. Steinbring, A. Watchman, P. Faulstich and P. S. C. Tacon (eds.), Time and space: dating and spatial considerations in rock art research, págs. 67-73. Occasional AURA Publication 8, Australian Rock Art Research Association, Melbourne.

CHASE, P.G., and DiBBLE, H.I. (1992): "Scientific archaeology and the origins of symbolism: a reply to Bednarik", Cambridge Archaeological Journal 2 (1), 43-51.

ClotTes, J.; Courtin, J., and ValladAs, H. (1992): "A well-dated Palaeolithic cave: the Cosquer Cave at Marseille", Rock Art Research 9, 122-29.

Davidson, I. (1992): "There's no art - To find the mind's construction - In offence", Cambridge Archaeological Journal 2, 52-57.

DAvIS, S.J.M. (1974): “Incised bones from the Mousterian of Kebara Cave (Mount Carmel) and the Aurignacian of Hayonim (Western Galilee), Israel", Paléorient 2, 181-82.

Debenath, A., and Duport, L. (1971): "Os travaillés et os utilisés de quelques gisements préhistoriques charentais", Mémoires, Société Archéologique et Historique de la Charente, 189-202.

Dorn, R.I.; Clarkson, P.B.; Nobes, M.F.; Loendorf, L.L., and Whitley, D.S. (1992): “New approach to the radiocarbon dating of rock varnish, with examples from drylands", Annals of the Association of American Geographers 82 (1), 136-51. 
Freeman, L.G., and Gonzalez Echegaray, J. (1983): "Tally-marked bone from Mousterian levels at Cueva Morín (Santander, Spain), in Homenaje al Prof. M. Almagro Basch, Vol. I, 143-47. Ministerio de Cultura, Madrid.

GOREN-INBAR, N. (1986): "A figurine from the Acheulian site of Berekhat Ram", Mi'Tekufat Ha'Even 19, 7-12.

Guidon, N., and Delibrias, G. (1986): "Carbon-14 dates point to man in the Americas 32,000 years ago", Nature $321,769-71$.

HAHN, J. (1971): “Eine jungpaläolithische Elfenbeinplastik aus dem Hohlenstein-Stadel», Fundberichte aus Schwaben, Neue Folge 19, 11-23.

HOWELL, F.C. (1966): "Observations of the earlier phases of the European Lower Palaeolithic", American Anthropologist 68 (2), 88-201.

Jones, R. (ed.) (1985): Archaeological research in Kakadu National Park, Canberra: Australian National Parks and Wildlife Service.

KEELEY, L.H. (1977): "The function of Paleolithic flint tools", Scientific American 237 (5), 108-26.

KELLOGG, R.; KNOLL, M., and KUGLER, J. (1965): "Form-similarity between phosphenes of adults and pre-school children's scribblings", Nature 208, 1129-30.

KLEIN, K. (1978): "Preliminary analysis of the mammalian fauna from the Redcliff Stone Age cave site, Rhodesia", Occasional Papers, National Museum of Southern Rhodesia A4 (2), 74-80.

Kumar, G.; Narvare, G., and Pancholi, R. (1988): “Engraved ostrich eggshell objects: new evidence of Upper Palaeolithic art in India", Rock Art Research 5, 43-53.

LEAKEY, L.S.B. (1958): “Recent discoveries at Olduvai Gorge, Tanganika", Nature 19, 10991103.

LEONARDI, P. (1988): “Art Paléolithique mobilier et pariétal en Italie", L'Anthropologie 92, 139-202.

Lumley, H. de (1966): "Les fouilles de Terra Amata à Nice. Premiers résultats", Bulletin du Musée d'Anthropologie Préhistorique de Monaco 13, 29-51.

MANIA, D., and MANIA, U. (1988): “Deliberate engravings on bone artefacts of Homo erectus", Rock Art Research 5, 91-107.

MARSHACK, A. (1976): "Some implications of the Paleolithic symbolic evidence for the origin of language", Current Anthropology 17 (2), 274-82.

- (1981): "On Paleolithic ochre and the early uses of color and symbol", Current Anthropology 22 (2), 188-91.

MARTIN, H. (1907-10): Récherches sur l'évolution du Moustérien dans le gisement de la Quina (Charente). Industrie osseuse, Vol. 1. Paris: Schleicher Frères.

NoBBs, M.F., and DoRN, R.I. (1988): "Age determinations for rock varnish formation within petroglyphs: cation-ratio dating of 24 motifs from the Olary region, South Australia", Rock Art Research 5, 108-46.

OAKLEY, K.P. (1981): "Emergence of higher thought, 3.0-0.2 Ma BP", Philosophical Transactions of the Royal Society of London B 292: 205-211.

RIEK, G. (1934): Die Eiszeitjägerstation am Vogelherd, Vol. I: Die Kulturen. Tübingen.

RoBeRTS, R.G.; JONES, R., and SIMITH, M.A. (1990): "Thermoluminescence dating of a 50,000-year-old human occupation site in northern Australia", Nature 345, 153-56.

SINGER, R., and WYMER, J. (1982): The Middie Stone Age at Klasies River Mouth in South Africa. University of Chicago Press, Chicago.

TYAGI, G.S. (1992): "Decorative intricate patterns in Indian rock art", in M. Lorblanchet (ed.), Rock Art in the Old World, 303-15. Indira Gandhi National Centre for the Arts, New Delhi.

VALOCH, K. (1987): “The early Palaeolithic site Stránská skála I near Brno (Czechoslovakia), Anthropologie 25, 125-42.

VÉRTES, L. (1964): Tata: eine mittelpaläolithische Travertin Siedlung in Ungarn. Akadémiai Kiadó, Budapest.

- (1965): Az öskökor és az átmeneti Kòkor emlékei Magyarországon. Akadémiai Kiadó, Budapest.

VOLMAN, T. (1984): "Early prehistory of southern Africa", in R. Klein (ed.), Southern African prehistory and palaeoenvironments, 169-220. Balkema, Rotterdam. 
WAKANKAR, V.S. (1983): "The oldest works of art?", Science Today 20, 43-48.

WATCHMAN, A. (1992): Preliminary geological and radiocarbon analysis of rock crusts in the Laura region. Paper presented to Symposium I, Second AURA Congress, Cairns.

WENDT, W.E. (1974): "Art mobilier aus der Apollo 11 Grotte in Südwest-Afrika", Acta Praehistorica et Archaeologica 5, 1-42. 